\title{
Distribution of helium-3 plumes and deep-sea circulation in the central Indian Ocean
}

\author{
Naoto Takahata ${ }^{1, *}$, Kotaro Shirai ${ }^{1}$, Kazuto Ohmori $^{2,3}$, Hajime Obata ${ }^{1}$, Toshitaka Gamo $^{1}$, and Yuji Sano ${ }^{1}$ \\ ${ }^{I}$ Atmosphere and Ocean Research Institute, The University of Tokyo, Chiba, Japan \\ ${ }^{2}$ Faculty of Sciences, Hokkaido University, Sapporo, Hokkaido, Japan \\ ${ }^{3}$ Geological Survey of Hokkaido, Hokkaido Research Organization, Sapporo, Hokkaido, Japan
}

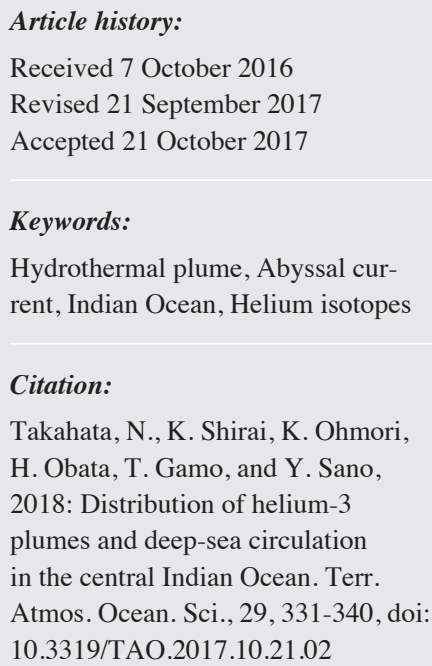

Received 7 October 2016 Revised 21 September 2017 Accepted 21 October 2017

Keywords:

Hydrothermal plume, Abyssal current, Indian Ocean, Helium isotopes

Citation:

Takahata, N., K. Shirai, K. Ohmori, H. Obata, T. Gamo, and Y. Sano, 2018: Distribution of helium-3 plumes and deep-sea circulation in the central Indian Ocean. Terr Atmos. Ocean. Sci., 29, 331-340, doi: 10.3319/TAO.2017.10.21.02

\begin{abstract}
We report helium isotope data collected in the central Indian Ocean, from the Arabian Sea to the Southern Ocean, during a Japanese GEOTRACES cruise in 2009 - 2010. We found hydrothermal helium-3 plumes and confirmed that ${ }^{3} \mathrm{He} /{ }^{4} \mathrm{He}$ ratio anomalies were almost the same as those observed in WOCE cruises conducted in 1990s, which indicates the hydrothermal activity and abyssal currents have not changed largely for the last few decades. Maximum $\delta^{3} \mathrm{He}$ value over $14 \%$ was observed at mid-depth $(2000-3000 \mathrm{~m})$ in the northern part (north of $\left.30^{\circ} \mathrm{S}\right)$ in the central Indian Ocean, whereas lower $\delta^{3} \mathrm{He}$ was found in the southern part at the same depth, where $\delta^{3} \mathrm{He}$ is defined as the percent deviation of the helium isotopic ratio relative to the atmospheric standard. The vertical distribution of $\delta^{3} \mathrm{He}$ shows a similar trend with dissolved iron and manganese distributions in the hydrothermal plume. Lateral $\delta^{3} \mathrm{He}$ distribution at mid-depth using our GEOTRACES data together with WOCE data suggest that the helium-3 plume in the central Indian Ocean derived from the Central Indian Ridge around $20^{\circ} \mathrm{S}$. It does not flow northward along the ridge but flows eastward as previously reported. The source of the helium-3 plume observed in the region adjacent to the Indian subcontinent might be in the Gulf of Aden as inferred from water properties. The $\delta^{3} \mathrm{He}$ distribution could reveal clockwise deepwater circulation in the Arabian Sea.
\end{abstract}

\section{INTRODUCTION}

Since the Indian Ocean is one of the three major oceans and has a mid ocean ridge in the center of the oceanic basin, it plays an important role for the global deep ocean circulation and for biogeochemical cycling of trace elements. However, useful data of trace elements for comprehensive understanding for the abyssal circulation are limited because the projects to observe geochemical properties in deep ocean were less frequently organized in the Indian Ocean. Further, the Arabian Sea is not safe in those days. It is also difficult to distinguish water masses in the deep ocean because water properties variations, such as temperature and salinity, are very small compared to those in shallower seawater. As we discuss below, the isotopic ratio of helium $\left({ }^{3} \mathrm{He} /{ }^{4} \mathrm{He}\right)$ dissolved in Indian Ocean seawater is at its maximum value at mid-depth rather than in the bottom waters due to ${ }^{3} \mathrm{He}$ input

\footnotetext{
* Corresponding author

E-mail:ntaka@aori.u-tokyo.ac.jp
}

from the Indian Ridge because the ridge crest where mantle gases are emitted is shallower than seafloor in other regions. So excess helium- 3 can be used for tracing movement and mixing of different water masses in these oceanic regions.

The ${ }^{3} \mathrm{He} /{ }^{4} \mathrm{He}$ ratio of the atmosphere is $1.4 \times 10^{-6}$, and it is considered to be constant on a global scale within an experimental error of 5\% (Sano et al. 2013). The ${ }^{3} \mathrm{He} /{ }^{4} \mathrm{He}$ ratios of mantle-derived samples, such as those from midocean ridge basalts and volcanic gases in island arcs, are relatively high at about $1 \times 10^{-5}$, whereas those from granitic rocks and continental natural gases are low, with ratios of $<1 \times 10^{-7}$ (Lupton 1983; Mamyrin and Tolstikhin 1984; Sano and Wakita 1985). The ${ }^{3} \mathrm{He} /{ }^{4} \mathrm{He}$ ratio is one of the most sensitive and conservative tracers in chemical oceanography (e.g., Jenkins et al. 1972; Craig et al. 1975; Sano et al. 1995) owing to its primordial signature, rapid mobility, and chemical inertness of helium. During the GEOSECS (Geochemical Ocean Sections Study) expedition in 1977 - 1978, 
Östlund et al. (1987) discovered a striking intensity and lateral extent of excess $\delta^{3} \mathrm{He}$ relative to air-saturated seawater in the deep Indian Ocean at $20^{\circ} \mathrm{S}$ on the Central Indian Ridge. This plume-shaped ${ }^{3} \mathrm{He}$ anomaly, which was originated from volcanic activity on the ridge, spread eastward by abyssal currents at the depth of the crest. After the GEOSECS survey, the Indigo Cruises (Jamous et al. 1992) and the WOCE (World Ocean Circulation Experiment) cruises (Srinivasan et al. 2004) obtained helium isotope data in a large area of the Indian Ocean. The WOCE was the largest internationally coordinated oceanographic program and a comprehensive global hydrographic survey of physical and chemical properties during the 1990s. They also reported excess $\delta^{3} \mathrm{He}$ of more than $10 \%$ at mid-depth $(2000-3000 \mathrm{~m})$ in the central Indian Ocean. Jean-Baptiste et al. (1992) and Kawagucci et al. (2008) found hydrothermal plumes with $\delta^{3} \mathrm{He}$ higher than $30 \%$ in the area of $18-20^{\circ} \mathrm{S}$ on the Central Indian Ridge, near the Rodriguez Triple Junction with anomalies of methane isotopes. Moreover, Gamo et al. (2001) found high temperature $\left(360^{\circ} \mathrm{C}\right)$ fluids near the Rodriguez Triple Junction and reported a very high ${ }^{3} \mathrm{He} /{ }^{4} \mathrm{He}$ ratio of $7.9 \mathrm{R}_{\mathrm{a}}$ of the vent fluid, where $\mathrm{R}_{\mathrm{a}}$ is the atmospheric ${ }^{3} \mathrm{He} /{ }^{4} \mathrm{He}$ ratio of $1.4 \times 10^{-6}$. This value is identical to that of the upper mantle $\left(8 \pm 1 \mathrm{R}_{\mathrm{a}}\right.$; e.g., Graham 2002). These observations imply that mid-ocean ridges in the Indian Ocean are very active just as in the Pacific Ocean. The $\delta^{3} \mathrm{He}$ maps have been used to infer abyssal currents based on the spreading of the mantle helium-3 signal because helium is a passive tracer.

Isopycnal maps made by Reid (2003) based on hydrographic data (i.e., temperature, salinity, oxygen, and silica) suggested abyssal currents in deep layers of the Indian Ocean. However eastward-spreading current inferred from the helium-3 plume observed at $20^{\circ} \mathrm{S}$ is not identical with that figured in Reid's map. Moreover, Reid's map suggests an anti-clockwise flow in the deep layer of the Arabian Sea, whereas Schlitzer (2007) estimated a clockwise flow, based on hydrographic and tracer data such as radiocarbon and chlorofluorocarbons. To precisely understand the deep circulation at mid-depth (2000 - $3000 \mathrm{~m})$ in the Indian Ocean, it is important to investigate the water mass structure from different approaches: for example, from the perspective of chemical oceanography as well of that of physical oceanography. In recent years, helium isotopes have been increasingly used to validate oceanic current models (Dutay et al. 2004, 2010). To confirm the hydrothermal plume and verify abyssal currents, we have characterized new distributions of ${ }^{3} \mathrm{He} /{ }^{4} \mathrm{He}$ ratios in seawater collected from the central Indian Ocean. We further estimated deep-sea circulation patterns at mid-depth in an area poorly known because of the scarce helium data available.

\section{EXPERIMENTAL METHOD}

Seawater sampling was conducted during a cruise onboard of the Hakuho Maru research vessel of the Japan Agency of Marine-Earth Science and Technology (JAMSTEC) in the central Indian Ocean (Japanese GEOTRACES cruise, KH-09-5, November 2009 to January 2010). Stations visited were ER2 (Bay of Bengal), ER5 to 8 (Arabian Sea), ER9 to 12 (central Indian Ocean), and ER14 (Southern Ocean). Figure 1 shows the sampling points. Samples for helium isotope measurements were collected from 4 11 depths at each station with a CTD (Conductivity Temperature Depth profiler) carousel system equipped with Niskin-X bottles. Details are shown in Table 1. Seawater was transferred without exposure to the atmosphere from the Niskin-X bottles into containers of about $30 \mathrm{~cm}^{3}$ made of copper tubing for storage (Sano et al. 1989). After connecting to the Niskin-X bottle with tygon tubing, the copper tubing was flushed with sample water from the Niskin-X bottle. Also, the tubing was tapped with a plastic hammer to detach adhered bubbles on the tubing wall. The tubing without bubble was closed at both ends with pinch-off tools.

In the laboratory, each $30-\mathrm{cm}^{3}$ copper container was connected to a stainless steel high vacuum line and dissolved gases were extracted from the seawater samples in vacuo. The dissolved gases were released from a water sample using an ultrasonic vibrator under vacuum. Water vapor was trapped in a U-shaped tubing held at liquid nitrogen temperature during extraction. Helium in the exsolved gases were purified with hot titanium-zirconium getters and charcoal traps held at liquid nitrogen temperature. The ${ }^{4} \mathrm{He} /{ }^{20} \mathrm{Ne}$ ratios were measured by an online quadrupole mass spectrometer. Helium was then separated from neon by a cryogenic charcoal trap held at $40 \mathrm{~K}$, because a varying $\mathrm{He} / \mathrm{Ne}$ ratio in terrestrial samples can affect the measured ${ }^{3} \mathrm{He} /{ }^{4} \mathrm{He}$ ratios by up to $10 \%$ (Rison and Craig 1983; Sano and Wakita 1988). The ${ }^{3} \mathrm{He} /{ }^{4} \mathrm{He}$ ratios were measured with a conventional noble-gas mass spectrometer (Helix-SFT, GV Instruments). Ion beams of ${ }^{3} \mathrm{He}$ and ${ }^{4} \mathrm{He}$ were measured by a double collector system. A resolving power of $>550$ at $1 \%$ of peak height was used for complete separation of the ${ }^{3} \mathrm{He}^{+}$ beam from those of $\mathrm{H}_{3}{ }^{+}$and $\mathrm{HD}^{+}$. The observed ${ }^{3} \mathrm{He} /{ }^{4} \mathrm{He}$ ratios of the samples were calibrated against atmospheric helium collected in Chiba, Japan. The experimental error of the ${ }^{3} \mathrm{He} /{ }^{4} \mathrm{He}$ ratio was about $0.7 \%(1 \sigma)$, estimated by repeated measurements of standard air containing concentrations equivalent to those of the samples and analytical error of each measurement of a water sample. As an additional check on the accuracy of the analytical system, we analyzed air-equilibrated seawater samples taken from a water reservoir in a thermostatically controlled room. The observed data agreed well with values reported in the literature (Kipfer et al. 2002) within the experimental error. The helium blank level (the same experimental procedure without the sample) was less than $1 \%$ of the level of the samples and the blank ${ }^{3} \mathrm{He} /{ }^{4} \mathrm{He}$ ratio was atmospheric within analytical error, and therefore negligibly affected the calibrated ratios. 


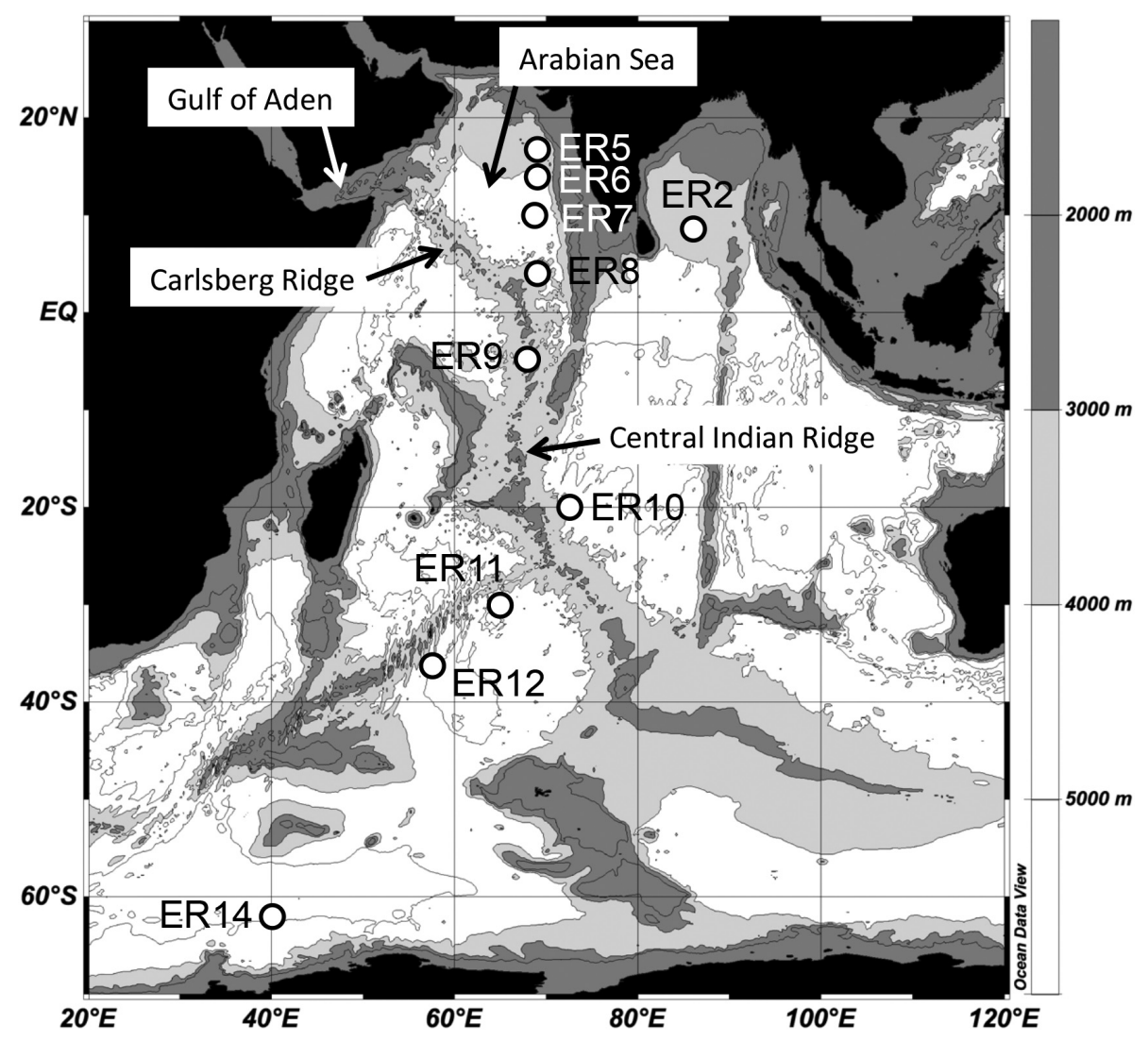

Fig. 1. A bathymetric map of the Indian Ocean with sampling sites. Depth of the ocean is contoured with the 2000, 3000, 4000, 5000 m isobaths, and depths shallower than $4000 \mathrm{~m}$ are shaded (light gray: $<4000 \mathrm{~m}$, dark gray: $<3000 \mathrm{~m}$ ).

Table 1. Location and bottom depth of sampling stations together with sampling depth of central Indian Ocean water.

\begin{tabular}{cccc}
\hline Station & Location & Bottom Depth $(\mathbf{m})$ & Sampling Depth $(\mathbf{m})$ \\
\hline ER2 & $08^{\circ} 31^{\prime} \mathrm{N}, 86^{\circ} 02^{\prime} \mathrm{E}$ & 3681 & $10,600,1000,1500,2000,2500,3000,3500$ \\
ER5 & $16^{\circ} 45^{\prime} \mathrm{N}, 69^{\circ} 00^{\prime} \mathrm{E}$ & 3624 & $1000,2000,2500,3000$ \\
ER6 & $14^{\circ} 00^{\prime} \mathrm{N}, 69^{\circ} 00^{\prime} \mathrm{E}$ & 4093 & $10,1000,1500,2000,2500,3000,3500,4000,4100$ \\
ER7 & $10^{\circ} 00^{\prime} \mathrm{N}, 68^{\circ} 45^{\prime} \mathrm{E}$ & 4510 & $10,1000,1500,2000,2500,3000,3500,4000,4500$ \\
ER8 & $04^{\circ} 00^{\prime} \mathrm{N}, 69^{\circ} 00^{\prime} \mathrm{E}$ & 4052 & $1000,1500,2000,3000,4000$ \\
ER9 & $05^{\circ} 16^{\prime} \mathrm{S}, 67^{\circ} 55^{\prime} \mathrm{E}$ & 3129 & $1000,1500,2000,2800,3100$ \\
ER10 & $20^{\circ} 00^{\prime} \mathrm{S}, 72^{\circ} 33^{\prime} \mathrm{E}$ & 4343 & $10,600,1000,1500,2000,2250,2500,3000,3500,4000,4300$ \\
ER11 & $30^{\circ} 00^{\prime} \mathrm{S}, 65^{\circ} 00^{\prime} \mathrm{E}$ & 4624 & $200,800,1000,1500,2000,2500,3000,3500,4000,4500$ \\
ER12 & $37^{\circ} 45^{\prime} \mathrm{S}, 57^{\circ} 37^{\prime} \mathrm{E}$ & 5296 & $200,600,800,1000,1500,2000,3000,3500,4000,4500,5000$ \\
ER14 & $62^{\circ} 00^{\prime} \mathrm{S}, 40^{\circ} 05^{\prime} \mathrm{E}$ & 5202 & $200,600,800,1000,1500,2500,3000,3500,4000,4500,5000$ \\
\hline
\end{tabular}




\section{RESULTS AND DISCUSSION}

\section{1 ${ }^{3} \mathrm{He} /{ }^{4} \mathrm{He}$ Ratios in the Central Indian Ocean}

Observed ${ }^{3} \mathrm{He} /{ }^{4} \mathrm{He}$ ratios are listed in Table 2 in $\delta^{3} \mathrm{He}$ notation, that is, the deviation of the helium isotopic ratio relative to the atmospheric standard, as follows:

$\delta^{3} \mathrm{He}(\%)=\left(\left[{ }^{3} \mathrm{He} /{ }^{4} \mathrm{He}\right]_{\text {seawater }} /\left[{ }^{3} \mathrm{He} /{ }^{4} \mathrm{He}\right]_{\text {air }}-1\right) \times 100$

Observed potential temperature and salinity are also listed in Table 2. Potential temperature is defined as the temperature of a water parcel at the sea surface after it has been raised adiabatically from some depth in the ocean. The $\delta^{3} \mathrm{He}$ values of the seawater samples varied from -1.6 to $16.3 \%$. In general, surface seawater is saturated with atmospheric noble gases because their exchange rate is rapid. The $\delta^{3} \mathrm{He}$ values increased downward, and maxima of about $15 \%$ were observed at mid-depth $(2000-3000 \mathrm{~m})$; they then decreased to about $10 \%$ in the bottom water. It is well known that at mid-depth, Indian Ocean waters are affected by mantle helium with a high $\delta^{3} \mathrm{He}$ value, possibly derived from the Central Indian Ridge (Östlund et al. 1987; Jamous et al. 1992; Jean-Baptiste et al. 1992; Srinivasan et al. 2004).

Figure 2 shows a vertical cross section of $\delta^{3} \mathrm{He}$ in the central Indian Ocean along our sampling stations. It is well documented that ${ }^{3} \mathrm{He}$ is slightly less soluble $(1.2 \pm 0.5 \%)$ in water than ${ }^{4} \mathrm{He}$ (Weiss 1971; Benson and Krause 1980). The $\delta^{3} \mathrm{He}$ values in surface waters $(\sim 10 \mathrm{~m}$ depth $)$ in the Indian Ocean were about $-1 \%$; they were consistent with the airsaturated seawater value of $-1 \%$ within analytical error. The $\delta^{3} \mathrm{He}$ values in intermediate water $(\sim 1000 \mathrm{~m}$ depth $)$ were lower in the southern part of the Indian Ocean compared with the northern part, which may indicate the recent intrusion of the surface water with low $\delta^{3} \mathrm{He}$ values (almost zero) not including mantle helium, or Antarctic Intermediate Water (Fine et al. 2008), which penetrates into all three oceans; the Indian, the Atlantic, and the Pacific (Fine 1993).

Maximum $\delta^{3} \mathrm{He}$ values of $>14 \%$ were observed at middepth (shaded area in Fig. 2). These maxima were lower than those observed at the same depth in the Pacific Ocean (Lupton 1998). It may be due to the difference of volcanic activities on the mid ocean ridges. There is a north-south gradient in $\delta^{3} \mathrm{He}$ values; higher in the northern part, lower in the southern part $\left(\sim 30^{\circ} \mathrm{S}\right)$ of the central Indian Ocean. This difference probably reflects a difference in the contribution of mantle helium, which is emitted from submarine volcanoes and brought by abyssal currents.

\subsection{Comparison of Our GEOTRACES Data with WOCE Data}

To draw distribution maps of the $\delta^{3} \mathrm{He}$ value in the Indian Ocean using our GEOTRACES data together with the
WOCE data, we firstly confirmed that the $\delta^{3} \mathrm{He}$ value at the same location has not changed. This was done by comparing our observation data with the WOCE data obtained about 15 years ago in the same area. We picked out two stations for comparison. One is station ER10, which is located in open ocean and largely influenced by mantle-derived helium from the Central Indian Ridge. The other is ER2, located at the margin of the Indian Ocean (Bay of Bengal).

Figure 3 shows vertical profiles of the $\delta^{3} \mathrm{He}$ value in seawater at ER10 (Fig. 3a) and ER2 (Fig. 3b). Solid circles with error bars indicate our GEOTRACES data, and broken lines indicate WOCE profiles. All stations illustrated in Fig. 3a are located at $20^{\circ} \mathrm{S}$ and we used the closest three points to ER10 among the WOCE I03 cruise data (CCHDO, http://whpo.ucsd.edu/). In Fig. 3b, we selected the closest three stations to ER2 among the WOCE I01 cruise data. As both figures show, our data are consistent with the WOCE data within our analytical error, which suggests the $\delta^{3} \mathrm{He}$ values in seawater at ER10 and ER2 have not changed for the last 15 years. It seems that the $\delta^{3} \mathrm{He}$ values in the deep Indian Ocean are maintained at steady-state. This means that hydrothermal activity and abyssal currents have not changed largely for the past 15 years. This timescale is much shorter than the overturning rate of the abyssal current. This enables us to draw distribution maps of the $\delta^{3} \mathrm{He}$ value in the Indian Ocean from our GEOTRACES data together with the WOCE data to investigate the origin and extent of the hydrothermal plume traced by $\delta^{3} \mathrm{He}$ anomalies mentioned in a later chapter.

\subsection{Vertical Distribution of Helium Isotopes Along the Sampling Sites}

As shown in Fig. 2, the relatively smaller increase of $\delta^{3} \mathrm{He}$ from the surface to $1000 \mathrm{~m}$ depth in the southern part (ER11 and 12) suggests the presence of the Antarctic Intermediate Water, which sinks at around $45-55^{\circ} \mathrm{S}$ and spreads northward at a depth of $1000-1800 \mathrm{~m}$. The feature of the Antarctic Intermediate Water was also found at $1000 \mathrm{~m}$ depth by looking at the distribution of the lead concentration (Echegoyen et al. 2014). On the other hand, a $\delta^{3} \mathrm{He}$ maximum was observed at mid-depth at ER $10\left(20^{\circ} \mathrm{S}\right)$. Gamo et al. (2001) found high temperature $\left(360^{\circ} \mathrm{C}\right)$ fluids with a very high ${ }^{3} \mathrm{He} /{ }^{4} \mathrm{He}$ ratio of $7.9 \mathrm{Ra}$ near the Rodriguez Triple Junction. Jean-Baptiste et al. (1992) and Kawagucci et al. (2008) found a hydrothermal plume with $\delta^{3} \mathrm{He}$ higher than $30 \%$ in the area of $18-20^{\circ} \mathrm{S}$ on the Central Indian Ridge. The hydrothermal plume found at $20^{\circ} \mathrm{S}$ in our cruise may be originated from the Central Indian Ridge near the Rodriguez Triple Junction. This area is one of the most active sources of hydrothermal helium-3 in the Indian Ocean (Srinivasan et al. 2004).

The region with $\delta^{3} \mathrm{He}$ values of higher than $14 \%$ spreads at mid-depth (2000 - $3000 \mathrm{~m}$ depth) from $20^{\circ} \mathrm{S}$ northward. 
Table 2. Potential temperature, salinity, and helium isotope ratio of central Indian Ocean water.

\begin{tabular}{|c|c|c|c|c|c|c|c|c|c|}
\hline Station & Depth (m) & P. Temperature $\left({ }^{\circ} \mathrm{C}\right)$ & Salinity & $\delta^{3} \mathrm{He}(\%)$ & Station & Depth (m) & P. Temperature $\left({ }^{\circ} \mathrm{C}\right)$ & Salinity & $\delta^{3} \mathrm{He}(\%)$ \\
\hline \multirow[t]{8}{*}{ ER2 } & 11 & 28.83 & 34.624 & $-1.2 \pm 0.6$ & ER10 & 992 & 4.57 & 34.533 & $9.5 \pm 0.7$ \\
\hline & 597 & 9.13 & 35.014 & $8.4 \pm 0.6$ & & 1486 & 3.69 & 34.711 & $13.1 \pm 0.7$ \\
\hline & 992 & 6.72 & 34.940 & $10.7 \pm 0.7$ & & 1979 & 2.49 & 34.723 & $14.9 \pm 0.7$ \\
\hline & 1486 & 4.44 & 34.852 & $13.7 \pm 0.7$ & & 2250 & - & - & $16.3 \pm 0.7$ \\
\hline & 1979 & 2.73 & 34.781 & - & & 2470 & 1.69 & 34.723 & $15.9 \pm 0.7$ \\
\hline & 2472 & 1.95 & 34.751 & $14.7 \pm 0.7$ & & 2962 & 1.35 & 34.725 & $14.5 \pm 0.7$ \\
\hline & 2963 & 1.52 & 34.733 & $13.4 \pm 0.7$ & & 3452 & 1.16 & 34.722 & $12.8 \pm 0.7$ \\
\hline & 3453 & 1.21 & 34.722 & $10.8 \pm 0.7$ & & 3941 & 1.11 & 34.720 & $12.3 \pm 0.7$ \\
\hline \multirow[t]{4}{*}{ ER5 } & 993 & 8.33 & 35.303 & $8.4 \pm 0.6$ & & 4306 & 1.10 & 34.719 & - \\
\hline & 1980 & 3.03 & 34.837 & $14.7 \pm 0.7$ & ER11 & 198 & 13.88 & 35.358 & $-0.6 \pm 0.6$ \\
\hline & 2471 & 2.06 & 34.774 & $14.7 \pm 0.7$ & & 794 & 8.57 & 34.631 & $2.9 \pm 0.7$ \\
\hline & 2961 & 1.61 & 34.748 & $15.0 \pm 0.7$ & & 992 & 5.49 & 34.401 & $4.2 \pm 0.6$ \\
\hline \multirow[t]{9}{*}{ ER6 } & 10 & 28.53 & 36.359 & $-1.6 \pm 0.7$ & & 1485 & 2.94 & 34.546 & - \\
\hline & 992 & 7.80 & 35.209 & $9.8 \pm 0.6$ & & 1976 & 2.19 & 34.694 & $10.3 \pm 0.7$ \\
\hline & 1489 & 5.00 & 34.981 & $12.5 \pm 0.7$ & & 2469 & 1.81 & 34.729 & - \\
\hline & 1982 & 2.96 & 34.830 & $13.5 \pm 0.7$ & & 2959 & 1.51 & 34.729 & $12.4 \pm 0.6$ \\
\hline & 2472 & 2.03 & 34.771 & 14.90 .7 & & 3449 & 1.19 & 34.721 & - \\
\hline & 2962 & 1.59 & 34.747 & $12.4 \pm 0.7$ & & 3936 & 0.61 & 34.693 & $8.2 \pm 0.7$ \\
\hline & 3452 & 1.45 & 34.739 & - & & 4423 & 0.37 & 34.693 & $7.9 \pm 0.6$ \\
\hline & 3940 & 1.39 & 34.736 & $11.9 \pm 0.7$ & ER12 & 198 & 15.39 & 35.501 & $-1.0 \pm 0.6$ \\
\hline & 4077 & 1.39 & 34.734 & - & & 595 & 12.15 & 35.107 & $-0.1 \pm 0.6$ \\
\hline \multirow[t]{9}{*}{ ER7 } & 10 & 29.07 & 36.542 & $-0.2 \pm 0.6$ & & 793 & 9.85 & 34.787 & $2.2 \pm 0.6$ \\
\hline & 995 & 7.83 & 35.170 & $8.9 \pm 0.7$ & & 990 & 7.61 & 34.558 & $3.0 \pm 0.6$ \\
\hline & 1489 & 4.95 & 34.942 & $13.2 \pm 0.7$ & & 1485 & 3.43 & 34.437 & - \\
\hline & 1977 & 2.95 & 34.819 & $13.8 \pm 0.7$ & & 1977 & 2.58 & 34.649 & $8.2 \pm 0.6$ \\
\hline & 2472 & 2.01 & 34.767 & $14.7 \pm 0.7$ & & 2958 & 1.76 & 34.765 & $8.8 \pm 0.7$ \\
\hline & 2965 & 1.59 & 34.746 & - & & 3445 & 1.12 & 34.736 & - \\
\hline & 3453 & 1.44 & 34.738 & $11.8 \pm 0.6$ & & 3934 & 0.34 & 34.695 & $7.7 \pm 0.7$ \\
\hline & 3944 & 1.36 & 34.736 & $11.8 \pm 0.7$ & & 4422 & 0.12 & 34.683 & - \\
\hline & 4427 & 1.32 & 34.731 & $11.6 \pm 0.7$ & & 4906 & 0.07 & 34.681 & $7.3 \pm 0.7$ \\
\hline \multirow[t]{5}{*}{ ER8 } & 993 & 6.99 & 35.024 & $8.7 \pm 0.6$ & ER14 & 199 & 1.45 & 34.600 & $9.0 \pm 0.6$ \\
\hline & 1487 & 4.50 & 34.877 & $12.0 \pm 0.8$ & & 593 & 1.30 & 34.714 & $10.1 \pm 0.6$ \\
\hline & 1981 & 2.66 & 34.788 & $14.4 \pm 0.7$ & & 791 & 1.10 & 34.716 & $8.6 \pm 0.7$ \\
\hline & 2963 & 1.56 & 34.744 & $13.1 \pm 0.6$ & & 988 & 0.90 & 34.711 & $9.0 \pm 0.7$ \\
\hline & 4013 & 1.39 & 34.737 & $11.9 \pm 0.7$ & & 1481 & 0.54 & 34.696 & - \\
\hline \multirow[t]{5}{*}{ ER9 } & 993 & 6.00 & 34.800 & $12.9 \pm 0.7$ & & 2461 & 0.03 & 34.675 & - \\
\hline & 1486 & 3.80 & 34.781 & $12.9 \pm 0.7$ & & 2949 & -0.16 & 34.668 & $6.3 \pm 0.6$ \\
\hline & 1980 & 2.56 & 34.762 & $14.9 \pm 0.7$ & & 3439 & -0.32 & 34.662 & $5.8 \pm 0.6$ \\
\hline & 2767 & 1.59 & 34.732 & $14.9 \pm 0.7$ & & 3926 & -0.44 & 34.658 & $6.4 \pm 0.7$ \\
\hline & 3125 & 1.48 & 34.730 & $14.7 \pm 0.7$ & & 4410 & -0.54 & 34.655 & $5.7 \pm 0.6$ \\
\hline \multirow[t]{2}{*}{ ER10 } & 11 & 25.38 & 35.134 & $-0.6 \pm 0.7$ & & 4895 & -0.61 & 34.653 & $4.4 \pm 0.6$ \\
\hline & 597 & 9.49 & 34.734 & $0.1 \pm 0.7$ & & & & & \\
\hline
\end{tabular}

Note: * Error assigned to the isotopic ratio is $1 \sigma$. 


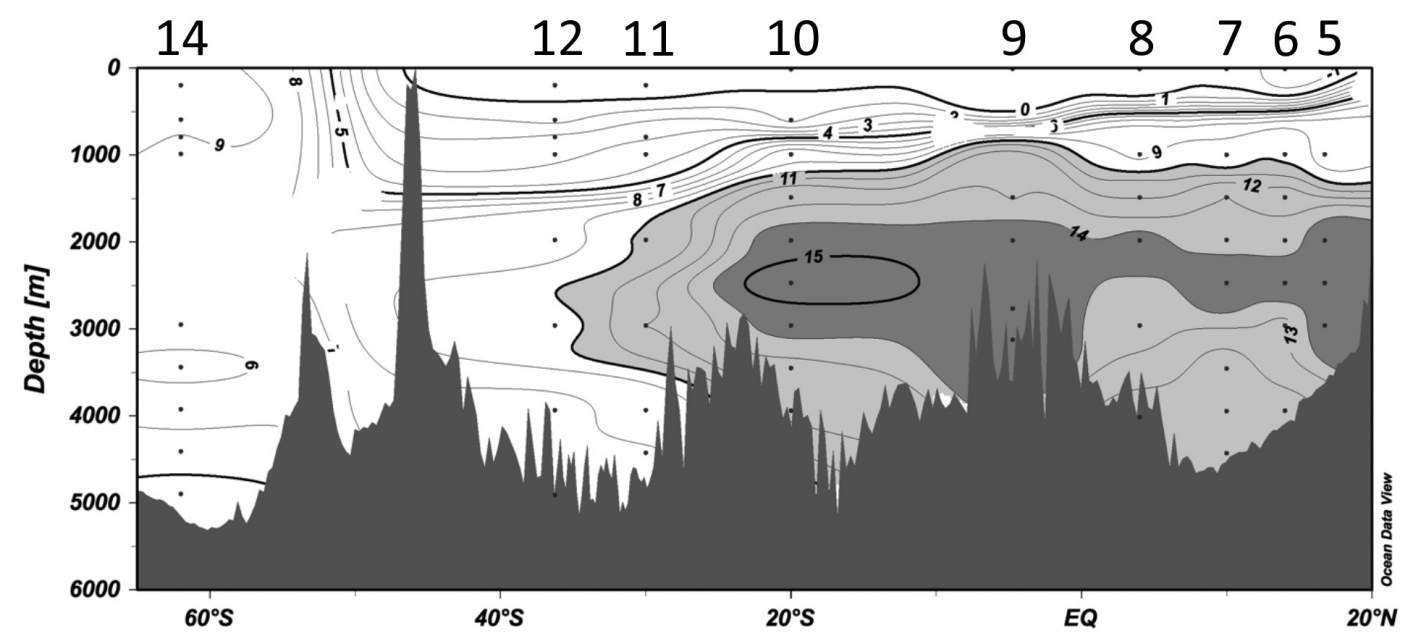

Fig. 2. Vertical distribution of excess ${ }^{3} \mathrm{He}$ (reported as $\delta^{3} \mathrm{He}$ values in $\%$ ) along the sampling sites of the central Indian Ocean. The numbers on the upper $\mathrm{x}$-axis indicate station numbers in our GEOTRACES cruise. Maximum $\delta^{3} \mathrm{He}$ values are observed at mid-depth in the northern part. The relatively smaller increase of $\delta^{3} \mathrm{He}$ near the surface in the southern part suggests that the shallow-water mixing layer is thicker toward the southern area in the central Indian Ocean.
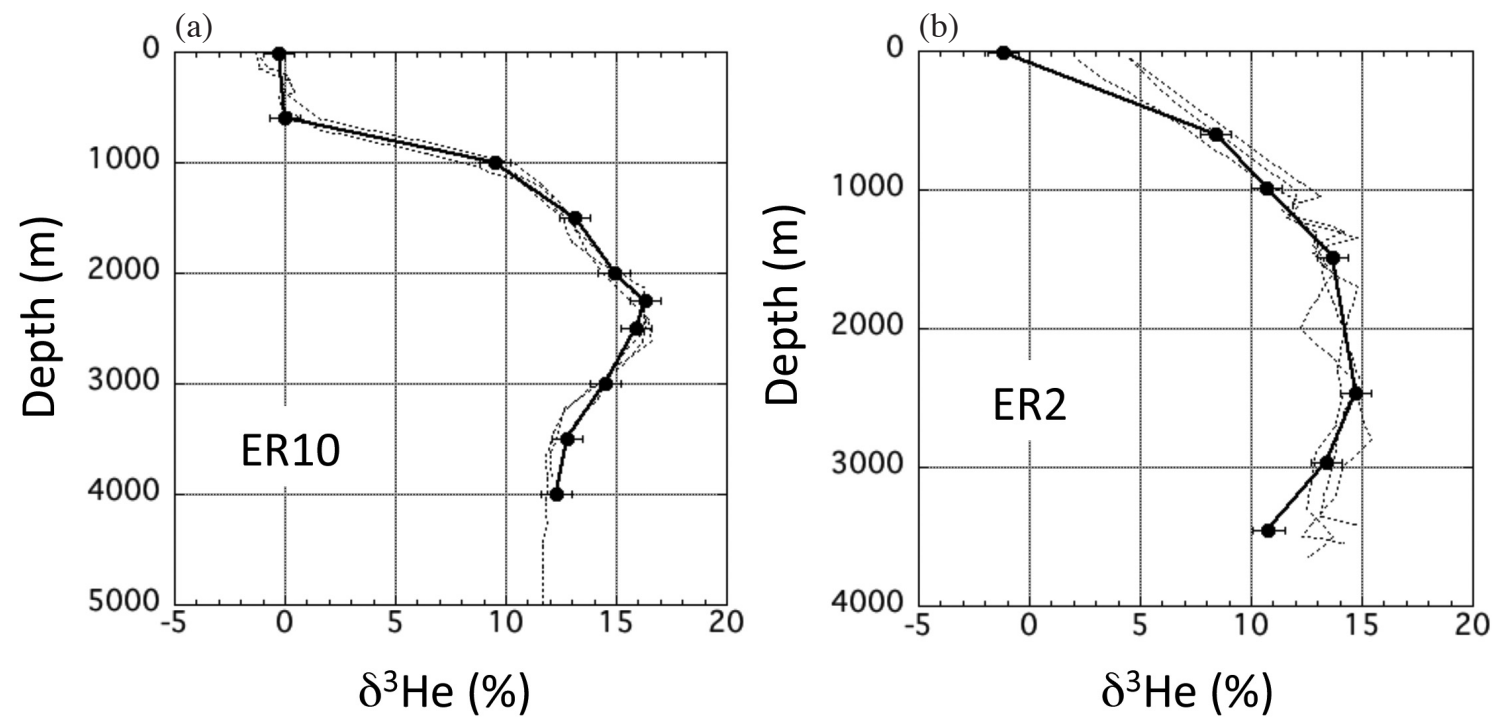

Fig. 3. Vertical profiles of excess ${ }^{3} \mathrm{He}$ (reported as $\delta^{3} \mathrm{He}$ values in \%) at two sampling sites [ER10 (a) and ER2 (b)] together with those at WOCE stations in the Indian Ocean. Solid circles indicate our GEOTRACES data and broken lines indicate WOCE profiles (the closest three stations to our sampling sites in I03 and I01 cruises).

In contrast, $\delta^{3} \mathrm{He}$ values are relatively lower at the same depth in the southern part. This trend is basically similar to those along two other meridional sections (WOCE I07: $55^{\circ} \mathrm{E}, \mathrm{I} 08$ and $\mathrm{I09}: 95^{\circ} \mathrm{E}$ from the CCHDO web site: http:// whpo.ucsd.edu/), where the $\delta^{3} \mathrm{He}$ value at mid-depth is also higher in the northern part, lower in the southern part. However, the $\delta^{3} \mathrm{He}$ value at $20^{\circ} \mathrm{S}$ in our section is higher than those measured along the two WOCE sections. Dissolved iron distributions indicate roughly similar trends of the hydrothermal plume (Nishioka et al. 2013; Thi Dieu Vu and Sohrin 2013); their data clearly show that the hydrothermal plume are distributed over $3000 \mathrm{~km}$ distance in the deep layer which is at an approximate depth of $3000 \mathrm{~m}$, around the Central Indian Ridge segment.

There are two possibilities to explain the high $\delta^{3} \mathrm{He}$ in the Arabian Sea; (1) mantle-derived helium emitted from a submarine volcano and/or (2) tritiogenic helium produced from bomb tritium. We measured the tritium concentration in deep seawater (2000 m depth) at the ER5 by helium-3 ingrowth method in our laboratory. It was very low at $<0.1$ T.U. (tritium units) and may not be bomb tritium. If it is bomb tritium, the present concentration should be higher than 1 T.U. because the concentration in precipitation was higher than 20 T.U. fifty years ago when atmospheric nuclear tests 
were conducted. Fifty years is equivalent to four half-life of tritium. Helium-3 produced from natural tritium decay cannot explain the high $\delta^{3} \mathrm{He}$ value of more than $10 \%$ in seawater because the natural tritium concentration in rainwater is not so high relative to bomb tritium. Fine et al. (2008) reported that chlorofluorocarbon concentrations in the WOCE study were very low and almost the same as the detection limit below $2000 \mathrm{~m}$ depth in the Arabian Sea. These lines of evidence suggest that bomb tritium cannot penetrate into deep layers below $2000 \mathrm{~m}$ depth in the Arabian Sea. Therefore, it is difficult to envisage that tritiogenic helium might have caused the high $\delta^{3} \mathrm{He}$ values up to $14 \%$ found in deep seawater near the Indian subcontinent. In order to investigate the source of the hydrothermal plume found in the Arabian Sea (ER5), we mapped the lateral distribution of $\delta^{3} \mathrm{He}$ at mid-depth.

\subsection{Lateral Distribution of Helium Isotopes at Mid-Depth}

Figure 4 shows a map of the lateral $\delta^{3} \mathrm{He}$ distribution in the Indian Ocean on an isopycnal surface defined by a potential density $\sigma_{\theta}=27.78$ (about $2000-3000 \mathrm{~m}$ depth) using our GEOTRACES data together with the previously reported WOCE data (CCHDO, http://whpo.ucsd.edu/). There are higher $\delta^{3} \mathrm{He}$ regions in the part north of $30^{\circ} \mathrm{S}$, while lower $\delta^{3} \mathrm{He}$ regions in the southern part. Lower $\delta^{3} \mathrm{He}$ observed in the southern part seems to be affected by the Circumpolar Deep Water of the Southern Ocean. This water mass mixes with other water masses such as the North Atlantic Deep Water and the Antarctic Bottom Water, in which helium isotopic ratios ( $\delta^{3} \mathrm{He}$ values) are relatively lower.

The helium-3 plumes were observed in the central part of the northern Indian Ocean and two possible sources of the plumes were found in Fig. 4; one is located around $20^{\circ} \mathrm{S}$ on the Central Indian Ridge; the other is located in the Gulf of Aden (Srinivasan et al. 2004). Helium-3 plumes were also found around $5^{\circ} \mathrm{N}$ over the Carlsberg Ridge (Ray et al. 2008, 2012) but the plume depth was deeper (>3000 $\mathrm{m}$ depth) than for the other hydrothermal sites (the Central Indian Ridge and the Gulf of Aden). Further, we did not identify the plume at $3000 \mathrm{~m}$ depth at ER8 $\left(4^{\circ} \mathrm{N}\right)$. Although Murton et al. (2006) found a hydrothermal event plume at $2500 \mathrm{~m}$ depth over the Carlsberg Ridge, this plume is not so long $(70 \mathrm{~km})$ and their observation sites were very close to the Carlsberg Ridge, which is far from our observation sites shown in Fig. 1. The hydrothermal input from the Carlsberg Ridge may not be so large relative to other sites.

The helium-3 plume detected in deep seawater off the western coast of the Indian subcontinent seems to be derived from either the Central Indian Ridge or the Gulf of Aden where a plume with $\delta^{3} \mathrm{He}$ of more than $40 \%$ was reported (Jean-Baptiste et al. 1990) together with $\mathrm{Mn}, \mathrm{Fe}$, and $\mathrm{CH}_{4}$ anomalies (Gamo et al. 2015). To investigate the source of the helium-3 plume found in the Arabian Sea (ER5 to 7), we inferred deep currents from the lateral $\delta^{3} \mathrm{He}$ distribution. Srinivasan et al. (2004) reported that the helium-3 plume around $20^{\circ} \mathrm{S}$ seemed to flow eastward at 2000-3000 $\mathrm{m}$ depth, based on the $\delta^{3} \mathrm{He}$ distribution. In order to check whether the helium-3 plume apparently flows northward from the Central Indian Ridge around $20^{\circ} \mathrm{S}$ to the region adjacent to the Indian subcontinent, we investigated the relationship between temperature and salinity in deep seawater.

Figure 5b shows that relationship in $2000-3000 \mathrm{~m}$ depth between temperature and salinity (T-S) as observed at the ER5 to 9 stations (this study) together with those at WOCE stations a - d shown in Fig. 5a. The numbers and alphabetical letters indicate stations shown in the Fig. 5a. Lines and Circles indicate our GEOTRACES and the WOCE data, respectively. Different gray scales in the circles mean different latitudes at which deep seawater was collected (white: $\sim 15^{\circ} \mathrm{N}$, gray: $\sim 10^{\circ} \mathrm{N}$, black: $\sim 5^{\circ} \mathrm{N}$ ). There is a clear difference between ER9 and the others. Figure $5 \mathrm{~b}$ indicates that water mass at the ER9 does not mix with water at the other stations whereas characteristics of water mass at all stations except for the ER9 are similar at $3000 \mathrm{~m}$ depth. This may indicate that deep water cannot flow across the equator, thus the helium-3 plume cannot extend from the $20^{\circ} \mathrm{S}$ region into the Arabian Sea. Moreover, there are similarities among seawater observed at similar latitude in the T-S diagram drawn in Fig. 5b. The water properties collected at ER5 and 6 are similar to that in the Gulf of Aden, while that at ER8 is similar to that at Station d. This suggests that the helium-3 plume flows eastward from the Gulf of Aden to the region adjacent to the Indian subcontinent, and deep water may flow clockwise in the Arabian Sea. Reid (2003) estimated an anti-clockwise flow in deep layers from physical water properties such as temperature, salinity and dissolved oxygen concentration. Schlitzer (2007) estimated a clockwise flow from hydrographic and tracer data such as radiocarbon and chlorofluorocarbons. Our result inferred from the $\delta^{3} \mathrm{He}$ distribution supports the clockwise pattern estimated by Schlitzer (2007).

\section{CONCLUSIONS}

We investigated helium isotopic ratios of 83 seawater samples collected in the central Indian Ocean to trace the source of a hydrothermal helium-3 plume and the figure out the deep-water circulation patterns at mid-depth (2000 - $3000 \mathrm{~m}$ depth). This was done by combining our new observations with literature data from WOCE program. Intermediate water ( $1000 \mathrm{~m}$ depth) had lower $\delta^{3} \mathrm{He}$ values in the southern part, suggesting a ventilation of the Antarctic Intermediate Water in the south Indian Ocean. High $\delta^{3} \mathrm{He}$ values of $>10 \%$ were observed at mid-depth in the central Indian Ocean from $30^{\circ} \mathrm{S}$ to the region adjacent to the Indian subcontinent. These maxima are lower than those observed in the South Pacific Ocean at the same depth. This 


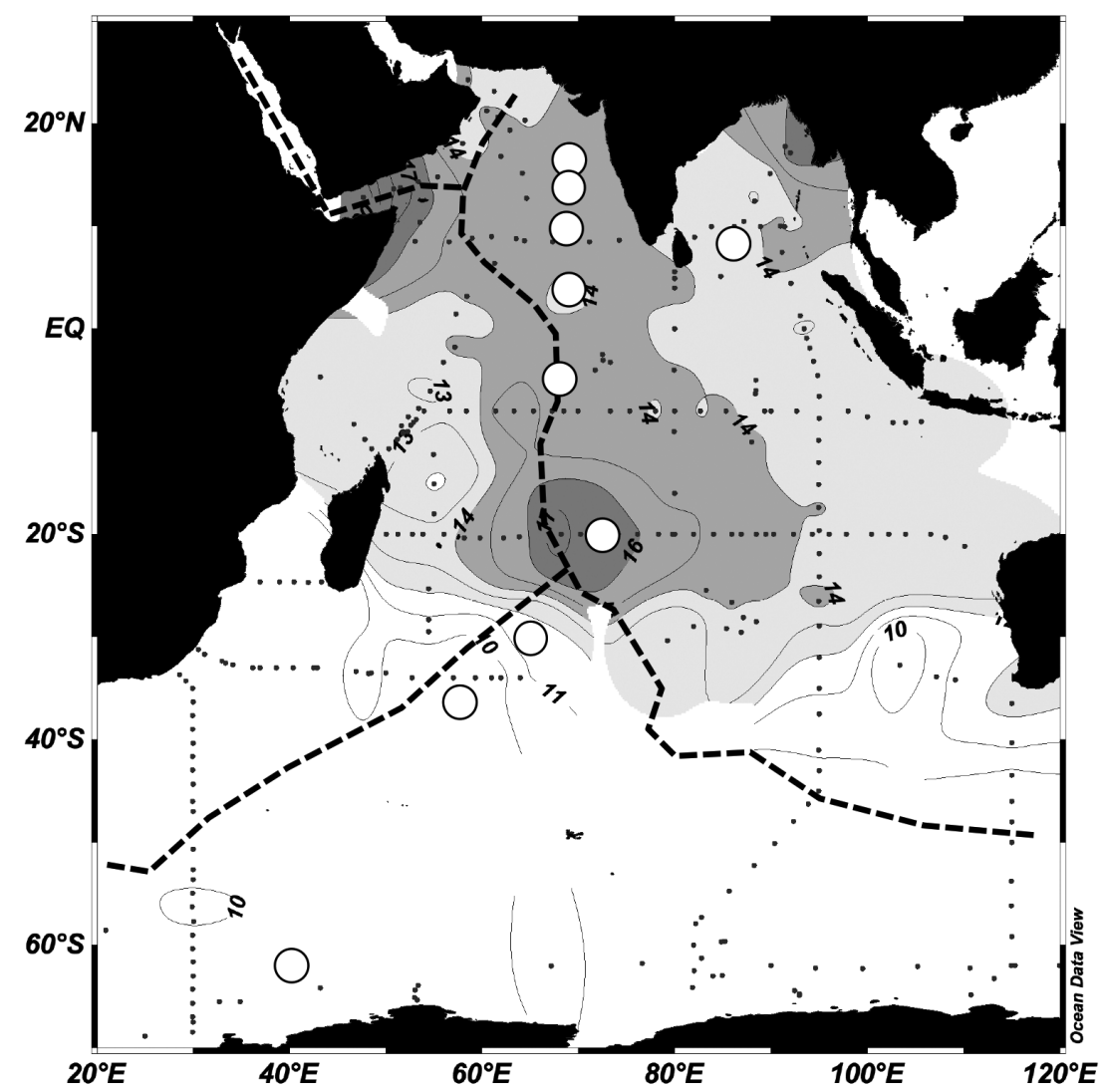

Fig. 4. Lateral distribution of $\delta^{3} \mathrm{He}(\%)$ in the Indian Ocean on an isopycnal surface defined by potential density $\sigma_{\theta}=27.78$. The dotted lines indicate plate boundaries including the mid-ocean ridge. The helium-3 plume observed in the northern region in the central Indian Ocean seems to be derived from the central Indian Ocean Ridge and/or the Gulf of Aden region.

(a)

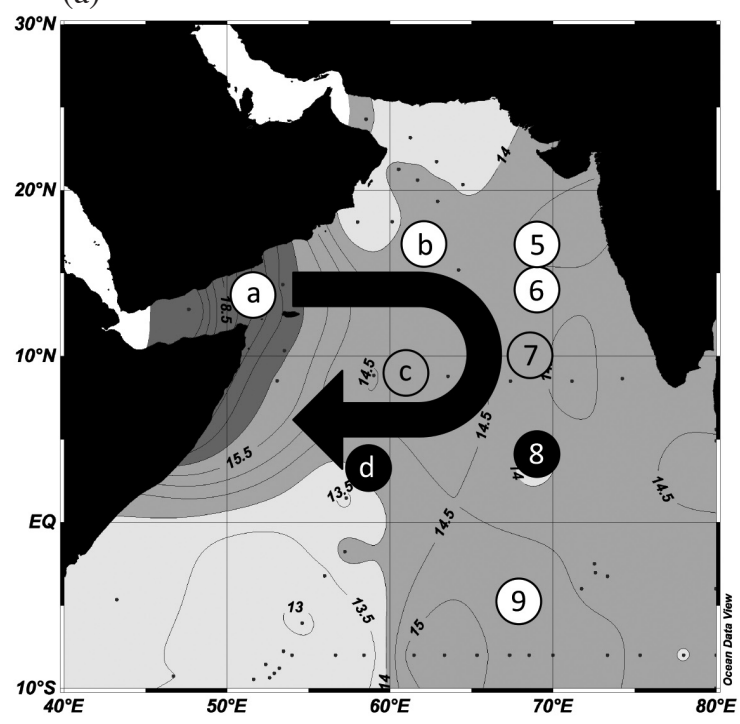

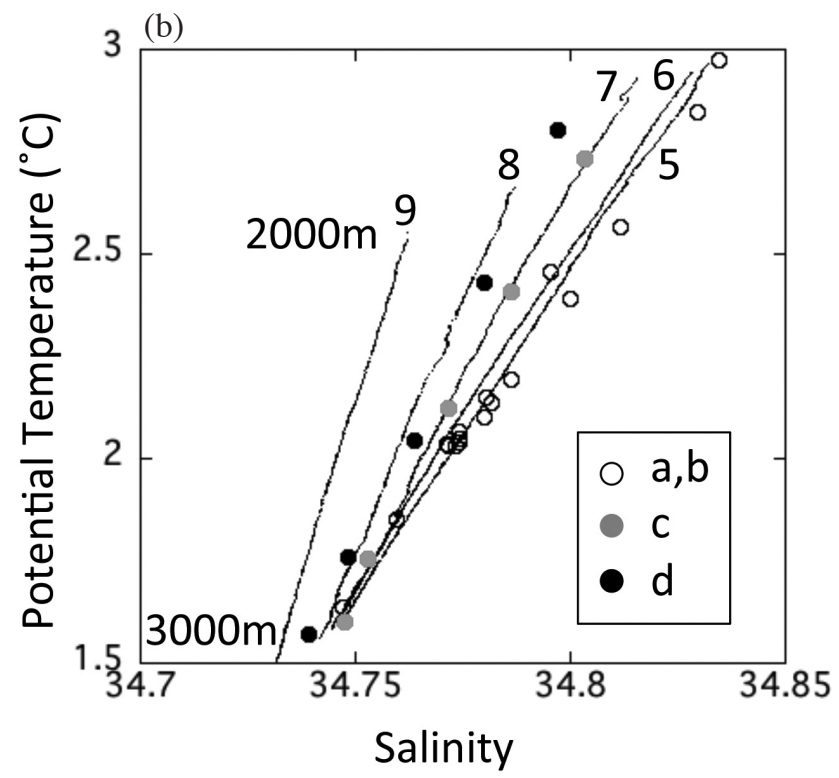

Fig. 5. (a) Lateral distribution of $\delta^{3} \mathrm{He}(\%)$ in the northern Indian Ocean on an isopycnal surface defined by potential density $\sigma_{\theta}=27.78$ and $(b)$ temperature-salinity diagrams between 2000 and $3000 \mathrm{~m}$ depth at the stations ER5 to 9 together with those at WOCE stations a - $d$ shown in (a). Whereas the water seems to flow clockwise in the Arabian Sea at 2000 - 3000 m depth, it doesn't seem to flow northward across the equator from ER9 to ER8. 
difference probably reflects a difference in hydrothermal activity of the mid-ocean ridge, or in the helium-3 emission rate. The lateral $\delta^{3} \mathrm{He}$ distributions at mid-depth together with hydrographic data suggest that helium-3 plume observed in the region adjacent to the Indian subcontinent flows from the Gulf of Aden. Deep water may flow clockwise in the Arabian Sea as inferred from $\delta^{3} \mathrm{He}$ and hydrographic data. The $\delta^{3} \mathrm{He}$ data obtained by this work could be used for improvement of deep-water circulation models estimated by other physical or chemical studies. It may lead to more comprehensive understanding for oceanic circulation of the region in the future.

Acknowledgements We are grateful to Dr. S. Niedermann and two anonymous reviewers for their helpful and constructive comments, and to Dr. S. Lin for the editorial handling. We thank the scientists of the KH-09-5 cruise and the crews of R/V Hakuho Maru for seawater sample collection and CTD observation. We also thank K. Toyoshima and T. Hara for help with seawater sampling and helium analysis. This work was partly supported by the Ministry of Education, Science, Sports and Culture, Japan, Grant-in-Aids for Scientific Research (No. 17101001 to YS).

\section{REFERENCES}

Benson, B. B. and D. Krause, 1980: Isotopic fractionation of helium during solution: A probe for the liquid state. J. Solut. Chem., 9, 895-909, doi: 10.1007/bf00646402. [Link]

Craig, H., W. B. Clarke, and M. A. Beg, 1975: Excess ${ }^{3} \mathrm{He}$ in deep water on the East Pacific Rise. Earth Planet. Sci. Lett., 26, 125-132, doi: 10.1016/0012-821X(75)900795. [Link]

Dutay, J. C., P. Jean Baptiste, J. M. Campin, A. Ishida, E. Maier Reimer, R. J. Matear, A. Mouchet, I. J. Totterdell, Y. Yamanaka, K. Rodgers, G. Madec, and J. C. Orr, 2004: Evaluation of OCMIP-2 ocean models' deep circulation with mantle helium-3. J. Mar. Syst., 48, 15-36, doi: 10.1016/j.jmarsys.2003.05.010. [Link]

Dutay, J. C., J. Emile-Geay, D. Iudicone, P. Jean-Baptiste, G. Madec, and C. Carouge, 2010: Helium isotopic constraints on simulated ocean circulations: Implications for abyssal theories. Environ. Fluid Mech., 10, 257273, doi: 10.1007/S10652-009-9159-Y. [Link]

Echegoyen, Y., E. A. Boyle, J. M. Lee, T. Gamo, H. Obata, and K. Norisuye, 2014: Recent distribution of lead in the Indian Ocean reflects the impact of regional emissions. Proc. Natl. Acad. Sci., 111, 15328-15331, doi: 10.1073/pnas.1417370111. [Link]

Fine, R. A., 1993: Circulation of Antarctic intermediate water in the South Indian Ocean. Deep-Sea Res. Part I-Oceanogr. Res. Pap., 40, 2021-2042, doi: 10.1016/0967-0637(93)90043-3. [Link]
Fine, R. A., W. M. Smethie, J. L. Bullister, M. Rhein, D. H. Min, M. J. Warner, A. Poisson, and R. F. Weiss, 2008: Decadal ventilation and mixing of Indian Ocean waters. Deep-Sea Res. Part I-Oceanogr.Res. Pap., 55, 20-37, doi: 10.1016/j.dsr.2007.10.002. [Link]

Gamo, T., H. Chiba, T. Yamanaka, T. Okudaira, J. Hashimoto, S. Tsuchida, J. Ishibashi, S. Kataoka, U. Tsunogai, K. Okamura, Y. Sano, and R. Shinjo, 2001: Chemical characteristics of newly discovered black smoker fluids and associated hydrothermal plumes at the Rodriguez Triple Junction, Central Indian Ridge. Earth Planet. Sci. Lett., 193, 371-379, doi: 10.1016/S0012821x(01)00511-8. [Link]

Gamo, T., K. Okamura, H. Hatanaka, H. Hasumoto, D. Komatsu, M. Chinen, M. Mori, J. Tanaka, A. Hirota, U. Tsunogai, and K. Tamaki, 2015: Hydrothermal plumes in the Gulf of Aden, as characterized by light transmission, $\mathrm{Mn}, \mathrm{Fe}, \mathrm{CH}_{4}$ and $\mathrm{\delta}^{13} \mathrm{C}_{-} \mathrm{CH}_{4}$ anomalies. Deep-Sea Res. Part II-Top. Stud. Oceanogr., 121, 62-70, doi: 10.1016/j.dsr2.2015.06.004. [Link]

Graham, D. W., 2002: Noble gas isotope geochemistry of mid-ocean ridge and ocean island basalts: Characterization of mantle source reservoirs. Rev. Mineral. Geochem., 47, 247-317, doi: 10.2138/rmg.2002.47.8. [Link]

Jamous, D., L. Mémery, C. Andrié, P. Jean-Baptiste, and L. Merlivat, 1992: The distribution of helium 3 in the deep western and southern Indian Ocean. J. Geophys. Res., 97, 2243-2250, doi: 10.1029/91JC02062. [Link]

Jean-Baptiste, P., S. Belviso, G. Alaux, B. C. Nguyen, and N. Mihalopoulos, 1990: ${ }^{3} \mathrm{He}$ and methane in the Gulf of Aden. Geochim. Cosmochim. Acta, 54, 111-116, doi: 10.1016/0016-7037(90)90199-U. [Link]

Jean-Baptiste,P.,F. Mantisi,H.Pauwells, D. Grimaud, and P. Patriat, 1992: Hydrothermal ${ }^{3} \mathrm{He}$ and manganese plumes at $19^{\circ} 29^{\prime} \mathrm{S}$ on the Central Indian Ridge. Geophys. Res. Lett., 19, 1787-1790, doi: 10.1029/92gl00577. [Link]

Jenkins, W. J., M. A. Beg, W. B. Clarke, P. J. Wangersky, and H. Craig, 1972: Excess ${ }^{3} \mathrm{He}$ in the Atlantic Ocean. Earth Planet. Sci. Lett., 16, 122-126, doi: 10.1016/0012-821x(72)90245-2. [Link]

Kawagucci, S., K. Okamura, K. Kiyota, U. Tsunogai, Y. Sano, K. Tamaki, and T. Gamo, 2008: Methane, manganese, and helium-3 in newly discovered hydrothermal plumes over the Central Indian Ridge, $18^{\circ}$ $20^{\circ}$ S. Geochem. Geophys. Geosyst., 9, Q10002, doi: 10.1029/2008gc002082. [Link]

Kipfer, R., W. Aeschbach-Hertig, F. Peeters, and M. Stute, 2002: Noble gases in lakes and ground waters. Rev. Mineral. Geochem., 47, 615-700, doi: 10.2138/ rmg.2002.47.14. [Link]

Lupton, J. E., 1983: Terrestrial inert gases: Isotope tracer studies and clues to primordial components in the mantle. Annu. Rev. Earth Planet. Sci., 11, 371-414, doi: 
10.1146/Annurev.Ea.11.050183.002103. [Link]

Lupton, J. E., 1998: Hydrothermal helium plumes in the Pacific Ocean. J. Geophys. Res., 103, 15853-15868, doi: 10.1029/98JC00146. [Link]

Mamyrin, B. A. and I. N. Tolstikhin, 1984: Helium Isotopes in Nature, Elsevier, Amsterdam, 273 pp.

Murton, B. J., E. T. Baker, C. M. Sands, and C. R. German, 2006: Detection of an unusually large hydrothermal event plume above the slow-spreading Carlsberg Ridge: NW Indian Ocean. Geophys. Res. Lett., 33, L10608, doi: 10.1029/2006GL026048. [Link]

Nishioka, J., H. Obata, and D. Tsumune, 2013: Evidence of an extensive spread of hydrothermal dissolved iron in the Indian Ocean. Earth Planet. Sci. Lett., 361, 26-33, doi: 10.1016/j.epsl.2012.11.040. [Link]

Östlund, H., H. Craig, W. S. Broecker, and D. Spencer, 1987: Shorebased data and graphics. GEOSECS Atlantic, Pacific and Indian Ocean Expeditions, Volume 7, National Science Foundation.

Ray, D., I. H. Mirza, L. S. Prakash, S. Kaisary, Y. V. B. Sarma, B. R. Rao, Y. K. Somayajulu, R. K. Drolia, and K. A. K. Raju, 2008: Water-column geochemical anomalies associated with the remnants of a mega plume: A case study after CR-2003 hydrothermal event in Carlsberg Ridge, NW Indian Ocean. Curr. Sci., 95, 355-360.

Ray, D., K. A. K. Raju, E. T. Baker, A. S. Rao, A. V. Mudholkar, J. E. Lupton, L. S. Prakash, R. B. Gawas, and T. V. Kumar, 2012: Hydrothermal plumes over the Carlsberg Ridge, Indian Ocean. Geochem. Geophys. Geosyst., 13, Q01009, doi: 10.1029/2011GC003888. [Link]

Reid, J. L., 2003: On the total geostrophic circulation of the Indian Ocean: flow patterns, tracers, and transports. Prog. Oceanogr., 56, 137-186, doi: 10.1016/S00796611(02)00141-6. [Link]

Rison, W. and H. Craig, 1983: Helium isotopes and mantle volatiles in Loihi Seamount and Hawaiian Island basalts and xenoliths. Earth Planet. Sci. Lett., 66, 407426, doi: 10.1016/0012-821X(83)90155-3. [Link]

Sano, Y. and H. Wakita, 1985: Geographical distribution of ${ }^{3} \mathrm{He} /{ }^{4} \mathrm{He}$ ratios in Japan: Implications for arc tectonics and incipient magmatism. J. Geophys. Res., 90, 87298741, doi: 10.1029/Jb090ib10p08729. [Link]

Sano, Y. and H. Wakita, 1988: Precise measurement of helium isotopes in terrestrial gases. Bull. Chem. Soc. Jpn., 61, 1153-1157, doi: 10.1246/Bcsj.61.1153. [Link]

Sano, Y., H. Wakita, J. Ishibashi, T. Gamo, and H. Sakai, 1989: Helium isotope ratios in Japan Sea water. Chikyukagaku, 23, 61-67, doi: 10.14934/chikyukagaku.23.61. (in Japanese). [Link]

Sano, Y., N. Takahata, and T. Gamo, 1995: Helium isotopes in South Pacific deep seawater. Geochem. J., 29, 377384, doi: 10.2343/geochemj.29.377. [Link]

Sano, Y., B. Marty, and P. Burnard, 2013: Noble gases in the atmosphere. In: Burnard, P. (Ed.), The Noble Gases as Geochemical Tracers, Advances in Isotope Geochemistry, Springer, Berlin, Heidelberg, 17-31, doi: 10.1007/978-3-642-28836-4_2. [Link]

Schlitzer, R., 2007: Assimilation of radiocarbon and chlorofluorocarbon data to constrain deep and bottom water transports in the world ocean. J. Phys. Oceanogr., 37, 259-276, doi: 10.1175/jpo3011.1. [Link]

Srinivasan, A., Z. Top, P. Schlosser, R. Hohmann, M. Iskandarani, D. B. Olson, J. E. Lupton, and W. J. Jenkins, 2004: Mantle ${ }^{3} \mathrm{He}$ distribution and deep circulation in the Indian Ocean. J. Geophys. Res., 109, C06012, doi: 10.1029/2003JC002028. [Link]

Thi Dieu Vu, H. and Y. Sohrin, 2013: Diverse stoichiometry of dissolved trace metals in the Indian Ocean. Sci. Rep., 3, doi: 10.1038/srep01745. [Link]

Weiss, R. F., 1971: Solubility of helium and neon in water and seawater. J. Chem. Eng. Data, 16, 235-241, doi: 10.1021/je60049a019. [Link] 